\title{
HISTORY OF THE ESTABLISHMENT AND DE- VELOPMENT OF THE CRAIG COLONY FOR EPILEPTICS LOCATED AT SONYEA, N. Y.
}

BY

DR. WILLIAM T. SHANAHAN, med. supt. Sonyea N. Y.

From the inception of public care of the insane in New York State, some epileptics were undoubtedly provided for from time to time. In 1873 Dr. Ordronaux referred to special provision for the epileptic on Blackwell's Island. In its Twelfth Annual Report, which appeared in 1879, the State Board of Charities referred to the matter as follows: "The subject of providing for the care and treatment of epileptics has long attracted wide attention, but thus far little has been accomplished regarding the matter, either in this or other countries". No special provision was existent beyond a separate ward. "That epileptics need intelligent oversight and care, equally with the insane, both on account of their helplessness and dangerous tendencies, is fully and very generally recognized." It then called attention to small percentage of possible recoveries but that proper care would prove wise economy, referring to hereditary tendencies of the condition.

As to the form of relief advisable, the Board felt that they were not called upon to decide, as wide differences of opinion existed among those familiar with the matter. They concluded: "The great importance of the subject certainly commends it to the thoughtful and earnest consideration of the Legislature".

In its Twenty-Eighth Report, the New York State Board 
of Charities states: „To Ohio belongs the honor of being the first State in the Union to provide a State institution exclusively for epileptics. It was through the forcible presentation to the Legislature, by the State Board of Charities, of the neglect, sufferings and needs of this peculiar class that the Governor of the State, in 1890 , was authorized by the Legislature to appoint a commission to select a site for an institution for their special care and medical treatment. This action, with subsequent legislation, resulting in the establishment of the Asylum for Epileptics and Epileptic Insane at Gallipolis, the cornerstone of which was laid November 12, 1891."

During the later 8o's certain persons, chief among whom was Dr. Frederick Peterson of New York City, agitated by addresses and published papers the providing of a separate institution, preferably a colony. Finally as members of the State Charities Aid Association, Dr. Frederick Peterson and Dr. George W. Jacoby were appointed a committee to report to the Association on State provision for epileptics, and on the strength of this report the State Charities Aid Association drew up and introduced into the Legislature of 1890 a bill for the selection of a site for such a colony. Failing to pass, it was reintroduced in 1892 , when it passed, and became a law on May 12 th of that year.

To meet its requirements, a committee of three commissioners of the State Board of Charities, consisting of the Hon. Oscar Craig, President; Hon. Wm. P. Letchworth, L. L. D.; and Mr. Peter Walrath, was named to select a suitable site and formulate plans pertaining to the establishment of a colony.

After inspecting several sites, the committee made a report recommending the purchase of the Shaker estate at Sonyea. The report was approved and a bill introduced into the Legislature in 1893 for the purchase of this property of 1895 acres and the establishment on it of a colony for epileptics. 
The following extracts from the Twenty-Eighth Annual Report show the trend of opinion of the State Board of Charities:

„By the terms of the statute the provision for epileptics is to be on neither the old institution plan, nor its ordinary modification by the substitution of detached buildings, as at Willard State Asylum. The colony idea is essential, as is shown by the express language of the law as well as its spirit, and by the needs and nature of the proper care and treatment of epileptics in community life. This colony design includes not only the separation of the patients into detached buildings, but the arrangement of the cottages upon irregular lines and at different distances, in accordance with the situations of the various building sites, adapted to the self-support of the inmates through natural advantages for economy of adninistration, and for the successful prosecution of trades, industries and agricultural labors."

"The indirect results of proper provisions for the medical treatment and education of epileptics, and their employment in the profitable prosecution of trades and industries and agricultural labors in colony life would be to remove from the alms-houses duties which they cannot discharge; and to release poor and indigent families 1rom their tendencies to become dependent upon charity, on account of their infirm members; and thus to promote a wise and true economy and public policy in the prevention of pauperism."

By Chapter 363 , Laws of 1894 , the Legislature authorized the purchase for II5000 of the Sonyea property for the purpose of establishing thereon a colony for epileptics under the title of Craig Colony, so named in honor of the late Oscar Craig, President of the State Board of Charities, thus commemorating the services rendered by him in behalf of the epileptics and other dependents of New York State.

The first Board of Managers was made up as follows: 
Dr. Frederick Pelerson, President

Mrs. C. F. Wadsworth,

Dr. Charles E. Jones,

Mr. W. H. Cuddeback,

Mr. George M. Shull, Secretary.

The Managers assumed office April 25, 1894. Directly after they reported: „Upon the property the Shakers formerly had two settlements each capable of accommodating one hundred or more people. The two settlements were to a certain extent distinct and occupied separate groups of buildings. One of these groups is known as the "West House", the other the "East House". Besides the buildings in the two groups, there are dwellings, some of which were used by people in the employ of the Shakers, a saw mill and other structures upon the premises. It was the opinion of the State Board of Charities, which is concurred in by the managers, that almost all the buildings can be made available for the purposes of the Colony."

"The statute requires the managers to adopt a general design for the establishment of an epileptic colony, to which all buildings and improvements now or hereafter erected or undertaken shall conform. To carry out this provision of the law, it became necessary to employ an architect and engineers, surveyors and others, to prepare plans and specifications for the various improvements contemplated by the managers."

The property was surveyed and plans outlining the location of buildings, landscape embellishments, etc. made by Olmsted Brothers of Brookline, Mass. The buildings to be erected were designed by Carriere and Hastings, Architects, who mentioned that "Although of harmonious design, each respective building was to vary from the others in detail and outline, so that its relation to them was not apparent. The external design of the several buildings was to be of a purely domestic nature, each appearing to represent a private residence in architectural 
character and proportion, and corridor and other structural connection avoided in order to fully dissipate institutional effects." The architects also stated "By the adoption of a dining-room in each respective building, the home life is maintained, and patients from several buildings are never massed together and embarrassed with the idea that they are a common lot, and furthermore a patient is thus not exposed to inclement weather, cold and storms (natural in this climate) in going through the open air to his meals, when probably (unknown to his care-takers) he may not be in a physical condition to warrant his doing so.

Dr. William P. Spratling was appointed Medical Superintendent on November $17^{\text {th, }} 1894$. He had previously been First Assistant Physician at Morris Plains State Hospital, New Jersey.

The first patient was admitted January 27, 1896. On August I, I9II, there were resident at the Colony 746 males, 655 females, $140 \mathrm{r}$ in all.

The number of buildings now at the Colony is over 10, nearly $4^{\circ}$ of which are occupied by Colonists, the remainder being officers' and employees' cottages, barns, store rooms, shops, railroad stations, etc. The patients' cottages vary in size, accommodating from 15 to 175 . The majority do not have a capacity exceeding 50 patients. The buildings for patients consisted, on August I, I9IJ, of the following:

Name of Building

Peterson Hospital

Schuyler Infirmary

Sage Pavilion for Tubercular Patients

Eleven Dormitory Cottages

Loomis Infirmary

Pryor Pavilion for Tubercular

Sixteen Dormitory Cottages Patients Males

Sex Capacity

Both

$5^{\circ}$

Females

162

Females

Females

Males

30

$17-60$

Males

162

30

$15-36$

Two Isolation Cottages for Con-

tagious Diseases

(I for each sex) 
Male patients are largely employed on the farm, in the garden and brickyard and in the dairy, work shops, households and with the various mechanics. The female patients work in the various households occupied by their sex, in the sewing room and in summer in the garden.

Over 150 of the younger Colonists of both sexes attend day and Sloyd school regularly during ten months of each year.

Religious matters are looked after by Resident Catholic and Protestant Chaplains and a Visiting Jewish Rabbi. This adds much to the feeling of contentment in the community.

Funds for a Catholic Chapel were donated in Igor. The Chapel was dedicated in April, 1902.

Efforts have been made to secure funds for the erection of a Protestant Chapel but up to the present the efforts have been comparatively fruitless.

The Protestant and Jewish services are held in the House of the Elders, the house of worship formerly used by the Shaker Colony.

The means of recreation are quite varied: baseball, basketball, croquet, band concerts, theatricals, annual field day, winter dances for female Colonists, club house for male Colonists, excursions to the neighbouring villages, etc., etc.

The situation seems admirably adapted by nature for the humane purpose to which it is devoted. Through the center of the tract, dividing it into two about equal portions, flows the Kishaqua Creek which serves admirably in providing a natural barrier for the separation of the two sexes.

The soil is greatly diversified, including a rich, sandy loam, clay and a rich alluvial deposit on the valley lands.

There is also a forest of 800 acres that still contains much fine hard wood.

Some twenty cottages have been built for married employees. 
In the haste to provide ordinary dormitories, many of the essentials such as central power and heating plant, amusement hall, observation cottages, nurses' homes, etc. have not been provided for as yet.

In the early days of the Colony the mistake was made of using exceedingly cheap construction for many dormitories. In consequence, the cost of up-keep is rather large.

The fire equipment consists of large hand chemical, hook and ladder, six hose carts, automatic whistle blower, etc.

Since the opening of the Colony, January 20, 1896, there have been admitted 1976 males, 1371 females, total 3347 .

The present valuation of the property is 1103692.36 .

Some two years ago a new institution for feebleminded and epileptic, the Letchworth Village, was established at Thiells, Rockland County, for the purpose of receiving certain low grade patients at that time and still in the other State Institutions for feebleminded and epileptic and also to relieve somewhat the number who are on the waiting list from the south-eastern part of the State. As a consequence of the establishment of this new institution, the development of Craig Colony has been checked as all efforts are being exerted by those in authority to push the erection of buildings at the new institution rather than add any to the number now at the Colony.

There is a laboratory at the Colony with a Resident Pathologist. This building is to be enlarged as soon as additional funds are received so that it will be possible to carry on a great deal more work than can be done with present facilities.

A training school for nurses is to be arranged for in such a way as to meet the requirements of the Education Department of the State of New York.

An employees' band plays at regular intervals-for dances for female patients during the winter and band concerts for all persons residing at the Colony during the summer months. 
There are several school teachers employed so that instruction in the ordinary branches and also in Sloyd work is given to both boys and girls whose mental condition permits their taking advantage of the same.

A considerable number of industries are carried on at the Colony: farming, gardening, mattress making, shoe repairing, painting, making of clothing, etc. One industry which gives employment to some twenty-five male patients is that of brick making, the present plant having a capacity of one million brick a year.

The amusements offered are the usual ones found in an institution of this type.

The staff consists of the Superintendent, Resident Pathologist and eight Assistant Physicians. The position of Resident Dentist has been created and one is to be employed.

A medical library of nearly three thousand volumes has been secured since the Colony was started and so far as funds permit is being kept up to date.

The number of employees at the present time is 220 . The ratio of those in direct charge of patients is I to II.

The following is a list of the present Board of Managers of the Colony:

$\begin{array}{ll}\text { Mr. Percy L. Lang, } & \text { President } \\ \text { Mr. Abbot Low Dow, } & \text { Secretary } \\ \text { Mr. Daniel B. Murphy, } & \\ \text { Mrs. Jeanette R. Hawkins, } & \\ \text { Dr. Frederick Peterson, } & \\ \text { Dr. George E. Gorham, } \\ \text { Mr. Barney S. Beuerlein, } \\ \text { Dr. William T. Shanahan, Medical Superintendent. }\end{array}$

THE REQUIREMENTS

FOR ELIGIBILITY FOR ADMISSION.

To be admitted to the Craig Colony for Epileptics, the patient must be a citizen of New York State. All patients are admitted on the same basis - as indigents. 
HISTORY OF THE ESTABLISHMENT AND DEVELOPMENT. I6I

Their financial standing is then inquired into by the Colony's agent and if it is found that the patient can reimburse the State in whole or in part, the patient must do so.

Admissions are regulated in accordance with the law which providees that equal favor be shown to every county in the State. The waiting list is always large. Epileptics of all ages are received - excepting infants in arms.

The first step to secure a patient's admission is to consult the Superintendent of the Poor or the Commissioner of Charities in the county or city in which the patient lives. He has the necessary application papers which must be filled out in every instance.

Under Chapter 588, Laws of I9II, certain custodial powers are given over patients at the Colony. 